\title{
Potential suppressive effects of theophylline on human rectal cancer SW480 cells in vitro by inhibiting YKL-40 expression
}

\author{
HONG PENG ${ }^{1,2}$, QIANG SU ${ }^{3}$, ZHONG-CHAO LIN ${ }^{1}$, XIU-HUA ZHU ${ }^{1}$, MING-SHA PENG ${ }^{1}$ and ZHEN-BING LV ${ }^{4}$ \\ ${ }^{1}$ Department of Anorectal Surgery, Nanchong Central Hospital; ${ }^{2}$ The Second Clinical College of \\ North Sichuan Medical College; Departments of ${ }^{3}$ Clinical Pharmacy and ${ }^{4}$ Gastrointestinal Surgery, \\ Nanchong Central Hospital, Nanchong, Sichuan 637000, P.R. China
}

Received August 17, 2016; Accepted January 5, 2018

DOI: $10.3892 / \mathrm{ol} .2018 .8220$

\begin{abstract}
Chitinase-3-like-1 protein (YKL-40), a member of the mammalian chitinase-like glycoproteins, serves a key role in the pathogenesis of rectal cancer. The present study examined the antitumor effect of theophylline, a pan-chitinase inhibitor, in rectal cancer in vitro and investigated the mechanism by which it acted. SW480 cell lines were treated with varying theophylline concentrations $\left(10^{-2}, 10^{-3}, 10^{-4}\right.$ and $\left.10^{-5} \mathrm{~mol} / \mathrm{l}\right)$. An MTT assay was used to observe cell proliferation and identify the optimal theophylline concentration. Western blotting was used to analyze YKL-40 expression. The cell cycle distribution of SW480 cell lines treated with theophylline was measured by flow cytometry. The angiopoietin-2 expression level was measured by ELISA. The expression levels of YKL-40 were evidently decreased in theophylline-treated SW480 cell lines. The proliferation ofSW480 cells was inhibited following theophylline treatment, which was associated with $\mathrm{G}_{1}$ phase cell cycle arrest and a decrease in the expression of angiopoietin-2. The mechanism of theophylline action may involve the downregulation of YKL-40 expression, arrest of the cell cycle at $G_{1}$ phase and inhibition of angiopoietin-2 expression. These results provide a rationale for the potential use of anti-YKL-40 and anti-angiogenic strategies in treating rectal cancer.
\end{abstract}

\section{Introduction}

Colorectal cancer is one of the most prevalent malignant tumors in the Asia-Pacific region, with a high mortality rate (1). To the best of our knowledge, the cause of the disease remains unknown, and surgical resection is the main treatment modality for the therapy of rectal cancer; however, $30 \%$ of these patients develop disease recurrence and metastasis (2).

Correspondence to: Mr. Qiang Su, Department of Clinical Pharmacy, Nanchong Central Hospital, 66 Dabei Street, Nanchong, Sichuan 637000, P.R. China

E-mail: 187169442@qq.com

Key words: chitinase inhibitor, rectal cancer, chitinase-3-like-1 protein, angiopoietin-2
Therefore, studies investigating novel therapeutic strategies, particularly molecular targeted agents, have become a topic of substantial interest.

Chitinase-3-like protein 1 (CHI3L1, also known as YKL-40) is a member of the mammalian chitinase-like protein family that is secreted by neutrophils, macrophages and tumor cells (3-5). YKL-40 serves a critical role in cellular proliferation, differentiation, angiogenesis, remodeling of the extracellular matrix and apoptosis (5-9), and the aforementioned processes are important for tumor growth and dissemination (10). Therefore, YKL-40 may represent a novel attractive therapeutic target.

Theophylline, a component of tea (Camellia sinensis), was identified as a pan-family 18 chitinase inhibitor, a family that includes YKL-40 and acidic mammalian chitinase. Recent evidence has shown that theophylline exhibits a potential anti-carcinogenic effect; however, to the best of our knowledge, the antitumor effect of theophylline on rectal cancer, and the precise etiology of disease, remains unknown. The aim of the present study was to evaluate the effect of theophylline on rectal cancer SW480 cells and investigate the mechanism by which this occurred.

\section{Materials and methods}

Cell culture and regents. Human rectal cancer SW480 cells were obtained from the Foundation Research Institute of Medical University of Chongqing (Chongqing, China) and were cultured in RPMI-1640 medium (Thermo Fisher Scientific, Inc., Waltham, MA, USA) supplied with $10 \%$ fetal bovine serum (Thermo Fisher Scientific, Inc.), $1 \%$ penicillin and $1 \%$ streptomycin (Thermo Fisher Scientific, Inc.) in a humidified atmosphere containing $5 \% \mathrm{CO}_{2}$ and $95 \%$ air at $37^{\circ} \mathrm{C}$. Theophylline $\left(\mathrm{C}_{7} \mathrm{H}_{8} \mathrm{~N}_{4} \mathrm{O}_{2}\right)$ was provided by Zhengzhou Shengyuan Industrial Co., Ltd. (Zhengzhou, China).

Cell proliferation. Rectal cancer SW480 cells $\left(1 \times 10^{5}\right)$ were seeded on a 96-well plate overnight and, when cells are $80 \%$ confluent, treated with varying theophylline concentrations $\left(0,10^{-2}, 10^{-3}, 10^{-4}\right.$ or $\left.10^{-5} \mathrm{~mol} / \mathrm{l}\right)$ for $48 \mathrm{~h}$. Following incubation of cells with $20 \mu \mathrm{l} \mathrm{MTT}(5 \mathrm{mg} / \mathrm{ml})$, the medium was discarded after 4 hand formazan crystals were dissolved in dimethyl sulfoxide $(150 \mu \mathrm{l})$. Next, the absorbance of each 
well was measured at $490 \mathrm{~nm}$. Experiments were performed three times in duplicate and the SW480 cell growth inhibition rate was calculated. The optimal inhibitory concentration of theophylline was $10^{-4} \mathrm{~mol} / \mathrm{l}$ at $48 \mathrm{~h}$ treatment times.

Western blotting. The rectal cancer SW480 cells $\left(2 \times 10^{5}\right)$ were seeded on a 6-well plate overnight and, when cells were $80 \%$ confluent, the treatment group was treated with $10^{-4} \mathrm{~mol} / 1$ theophylline for $48 \mathrm{~h}$, the negative group was treated with RPMI-1640 medium and the blank group was not treated for $48 \mathrm{~h}$. The cells were lysed in Radioimmunoprecipitation assay lysis buffer on ice for $30 \mathrm{~min}$ and centrifuged for $10 \mathrm{~min}$ at $12,000 \times \mathrm{g}$ at $4^{\circ} \mathrm{C}$. Whole cell lysates $(30 \mu \mathrm{g})$ were separated on $12 \%$ SDS polyacrylamide gels and were transferred to polyvinylidene difluoride membranes. Membranes were blocked in 5\% non-fat milk in TBS and 0.1\% Tween-20 at room temperature for $2 \mathrm{~h}$. YKL-40 (rabbit anti-human; cat. no. Ab3427; Shanghai Yanjing Biotech Engineering Co., Ltd., Shanghai, China; dilution, 1:1,000) and $\beta$-actin (rabbit anti-human; cat. no. yb-0061R; Shanghai Yubo Biotech Engineering Co., Ltd., Shanghai, China; dilution, 1:1,000) antibodies were used in the western blotting analysis. Subsequent to washing with TBST (TBS containing $0.05 \%$ Tween-20, $\mathrm{pH}$ 7.6) three times, the membranes were incubated with goat anti-rabbit immunoglobulin $\mathrm{G}$ conjugated to horseradish peroxidase (cat. no. ab97051; 1:2,000; Abcam, Cambridge, MA, USA) for $1 \mathrm{~h}$ at room temperature. Densitometric analysis was performed using Quantity One software (version 4.0, Bio-Rad Laboratories, Inc., Hercules, CA, USA).

Flow cytometry. The rectal cancer SW480 cells $\left(2 \times 10^{5}\right)$ were seeded on a 6 -well plate overnight and when cells are $80 \%$ confluent. The treatment group was treated with $10^{-4} \mathrm{~mol} / \mathrm{l}$ theophylline for $48 \mathrm{~h}$. The negative group was treated with RPMI-1640 medium and the blank group was not treated for $48 \mathrm{~h}$. Flow cytometry analysis was performed by BD FACSCalibur (BD Biosciences, Franklin Lakes, NJ, USA) and analyzed by MODFit LT version 3.3 software (BD Biosciences). The fraction of the total cell population present in the $G_{1}, S$ and $G_{2} / M$ phases was obtained.

ELISA. The rectal cancer SW480 cells $\left(2 \times 10^{5}\right)$ were seeded on a 24 -well plate overnight and when $80 \%$ confluent, treated. The treatment group was treated with $10^{-4} \mathrm{~mol} / \mathrm{l}$ theophylline for $48 \mathrm{~h}$. The negative group was treated with RPMI-1640 medium and the blank group was not treated for $48 \mathrm{~h}$. The level of angiopoietin-2 was measured using an ELISA kit (cat. no. MM-0309H1; Shenzhen Jingmei Biotech Engineering Co., Ltd., Shenzhen, China).

Statistical analysis. Qualitative variables were expressed as the count (percentage); quantitative variables were expressed as the mean \pm standard deviation. Differences between two groups with a normal distribution were assessed using a Student's t-test for non-normal distributions, the Mann-Whitney rank-sum test was used. Analysis of variance was performed to evaluate the difference $>2$ groups followed by Tukey's post hoc test. All statistical analyses were performed using SPSS version 17 (SPSS, Inc., Chicago, IL, USA). P<0.05 was considered to indicate a statistically significant difference.
Table I. Cell viability following culture with different theophylline concentration.

\begin{tabular}{lcc}
\hline Group, mol/l & OD value & Cell viability, \% \\
\hline 0 & $0.57 \pm 0.04$ & N/A \\
$10^{-5}$ & $0.50 \pm 0.04$ & 87.71 \\
$10^{-4}$ & $0.45 \pm 0.03$ & 78.95 \\
$10^{-3}$ & $0.44 \pm 0.03$ & 77.20 \\
$10^{-2}$ & $0.43 \pm 0.03$ & 75.44
\end{tabular}

Chitinase-3-like protein 1expression was analyzed by western blotting. OD, optical density; N/A, not applicable.

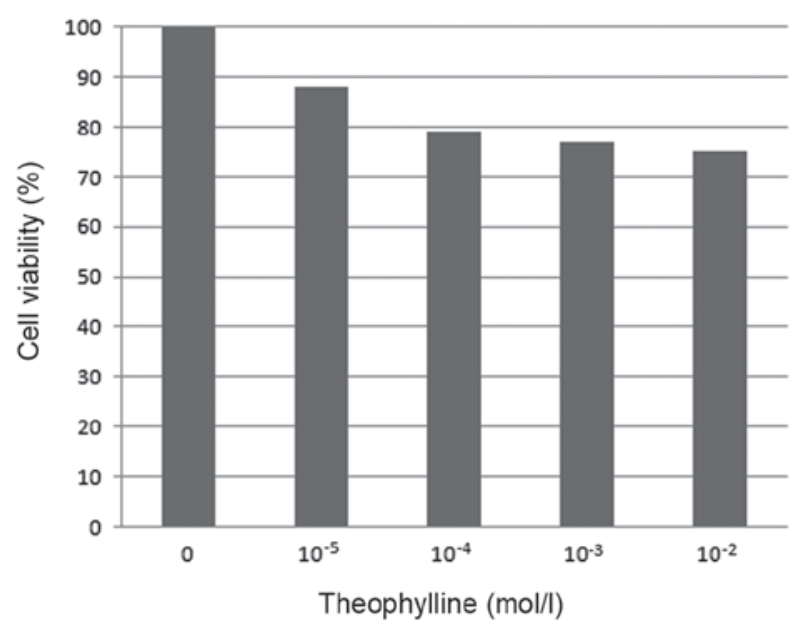

Figure 1. Effect of theophylline on SW480 cell viability.

\section{Results}

In vitro effects on cell proliferation. The viability of SW480 cells decreased markedly with increases in theophylline concentration $\left(10^{-5}-10^{-2} \mathrm{~mol} / \mathrm{l}\right)$; however, there was no significant difference in SW480 cell viability following culture with higher concentrations of theophylline $\left(10^{-4}-10^{-2} \mathrm{~mol} / \mathrm{l}\right)$, indicating that the optimal inhibitory concentration of theophylline was $\sim 10^{-4} \mathrm{~mol} / \mathrm{l}$ at $48 \mathrm{~h}$ treatment times. Therefore, a concentration of $10^{-4} \mathrm{~mol} / \mathrm{l}$ was used for all subsequent investigations (Table I and Fig. 1).

Western blotting. Densitometry value analysis was used to assess YKL-40 expression and were repeated 10 times. The result revealed that Densitometry value in the treatment group, the negative group and the blank group were 11,848.7 \pm 92.2 , 13,503.2 \pm 68.8 and 13,572.8 \pm 49.9 , respectively, which indicated that YKL-40 protein expression decreased significantly in the treatment group compared with the negative and the blank groups $(\mathrm{F}=1,816 ; \mathrm{P}<0.05)$. However, there was no significant difference in YKL-40 expression between the negative group and blank group (Fig. 2).

Flow cytometry assessment of cell cycle distribution. The SW480 cell cycle progression was assessed after $48 \mathrm{~h}$ culture with theophylline. The result indicated that the cell cycle was 
Table II. Cell cycle distribution analysis.

\begin{tabular}{lccc}
\hline Group & $\mathrm{G}_{0} / \mathrm{G}_{1}$ phase, $\%$ & S phase, $\%$ & $\mathrm{G}_{2} / \mathrm{M}$ phase, $\%$ \\
\hline Negative & $67.72 \pm 3.65^{\mathrm{a}}$ & $25.17 \pm 2.68$ & $7.10 \pm 1.25$ \\
Blank & $66.67 \pm 7.16^{\mathrm{a}}$ & $24.96 \pm 7.96$ & $8.35 \pm 1.82$ \\
Treatment & $81.32 \pm 2.89$ & $14.27 \pm 4.02$ & $4.42 \pm 1.92$ \\
\hline
\end{tabular}

Data are presented as the mean \pm standard deviation. ${ }^{\mathrm{a}} \mathrm{P}<0.05$ compared with the treatment group.

Table III. Angiopoietin-2 expression level.

\begin{tabular}{lc}
\hline Group & Angiopoietin-2, ng/ml \\
\hline Negative & $39.1 \pm 2.18^{\mathrm{a}}$ \\
Blank & $40.6 \pm 2.07^{\mathrm{a}}$ \\
Treatment & $29.2 \pm 2.04$ \\
\hline
\end{tabular}

${ }^{\text {a }}<0.05$ compared with the treatment group.

A 1

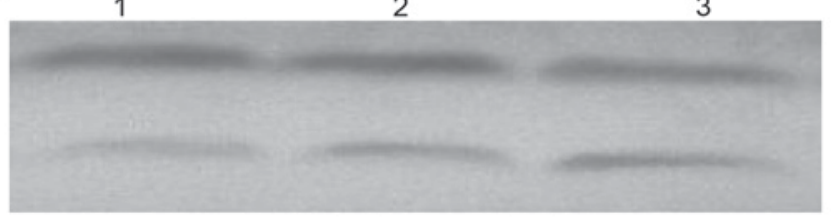

B

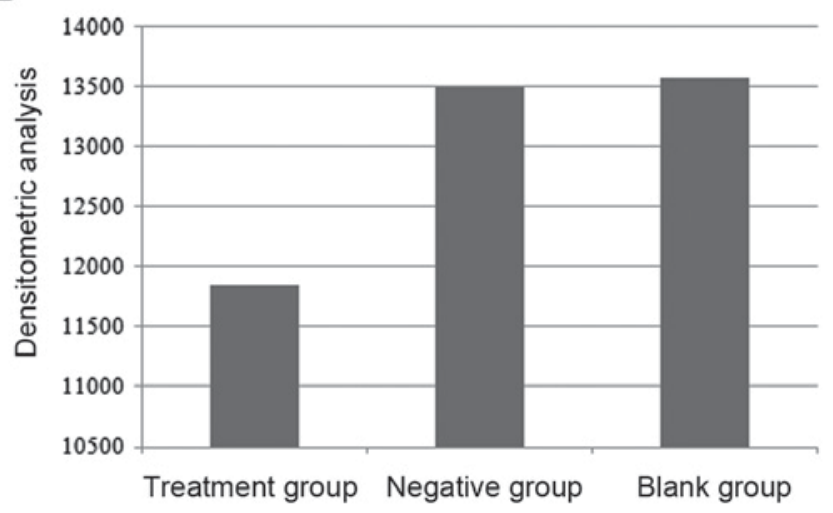

Figure 2. YKL-40 expression. (A) YKL-40 expression levels in different group. Lane 1, treatment group $\left(10^{-4} \mathrm{~mol} / 1\right.$ theophylline); lane 2, negative (medium-treated) group; lane 3, blank (untreated) group. Bottom bands represents YKL-40; Top bands represents $\beta$-actin. (B) Densitometric analysis. YKL-40, Chitinase-3-like-1 protein.

arrested in the $G_{1}$ phase in $81.32 \%$ of treatment group cells, compared with $67.72 \%$ of negative group cells and $66.67 \%$ of blank group cells. Therefore, suppressing YKL-40 expression attenuated SW480 cell proliferation by arresting the cell cycle in $\mathrm{G}_{1}$ phase (Table II and Fig. 3).

Angiopoietin-2 expression level in SW480 cells. In the treatment group, the angiopoietin-2 expression level decreased significantly compared with the negative group and the blank group $(\mathrm{F}=87.13 ; \mathrm{P}<0.05)$. However, there was no significant difference in angiopoietin-2 expression between the negative group and blank group (Table III).

\section{Discussion}

Previous studies have demonstrated that YKL-40 is associated with oncogenesis $(8,10)$. Elevated levels of serum YKL-40 were reported to be associated with several types of cancer, such as ovarian, esophageal, breast, lung, liver and kidney cancer (11-16). Furthermore, high expression of YKL-40 is associated with tumor grade, poor differentiation and shorter overall survival times, and may be a potential biomarker $(5,11,13)$. Research by Johansen et al (17) revealed the presence of high levels of serum YKL-40 in patients with rectal cancer, meaning it may be a useful candidate biomarker for colorectal cancer risk assessment. Chen et al $(18,19)$ confirmed that YKL-40 was highly expressed in the SW480 cell line, that treatment with exogenous YKL-40 could significantly promote SW480 proliferation and migration, and that YKL-40 serves a key role in inflammation-associated neoplastic changes. YKL-40 protein markedly enhanced nuclear factor- $\kappa \mathrm{B}(\mathrm{NF}-\kappa \mathrm{B})$ signaling pathway activation, and NF- $\mathrm{KB}$ efficiently promoted proliferation of tumor cells (20). Shao et al (21) demonstrated that ectopic YKL-40 could stimulate colon cancer HCT-116 cell angiogenesis and tumor progression. In addition, YKL-40 restrained apoptosis by enhancing the activation of mitogen-activated protein kinase and phosphoinositide 3-kinase signaling cascades, and suppressing the expression of the pro-apoptotic S100A9 protein (22-24). Generally, YKL-40 serves a vital role in the pathogenesis of rectal cancer. Therefore modulating YKL-40 functions may represent an efficient strategy for rectal cancer prevention and treatment.

In recent years, certain compounds extracted from traditional herbal medicines and plants have indicated potential at preventing and curing tumors (25). Theophylline is the main constituent and characteristic component of the purine alkaloids found in tea plants; it is also a specific inhibitor of YKL-40 (26). Chang et al (27) suggested that theophylline exerts an antitumor effect; however, to the best of our knowledge, no research on theophylline in rectal cancer has been reported. The results of the present study revealed that theophylline could perform preventive actions for rectal cancer, demonstrating that in vitro the rectal cancer SW480 cells viability decreased significantly with as theophylline concentration increased (from $10^{-5}$ to $\left.10^{-2} \mathrm{~mol} / \mathrm{l}\right)$. One mechanism responsible for this protection were mediated via suppression of YKL-40 expression by theophylline, which was analyzed by western blotting in the present study. In addition, the result indicated the cell cycle was arrested in $G_{1}$ phase in $81.32 \%$ of SW480 cells cultured with theophylline. Chen et al (19) revealed YKL-40 could activate the Akt signaling pathway in colonic epithelial cells subsequent to phosphorylating the Thr 308 residue, and Sheng et al (28) demonstrated that expression of active Akt increased the expression of cyclin D1 and promoted S phase entry, and that the inhibition of the PI3k/Akt pathway resulted in accumulation of RIE cells in the G1 phase of the cell cycle. Eurich et al (29) demonstrated that a low dose of YKL-40 could be used to stimulate SW480 cell, could resulting in $\beta$-catenin nuclear translocation and subsequent activation of the transcription of target genes, including c-Myc and cyclin D1, then induce 
A

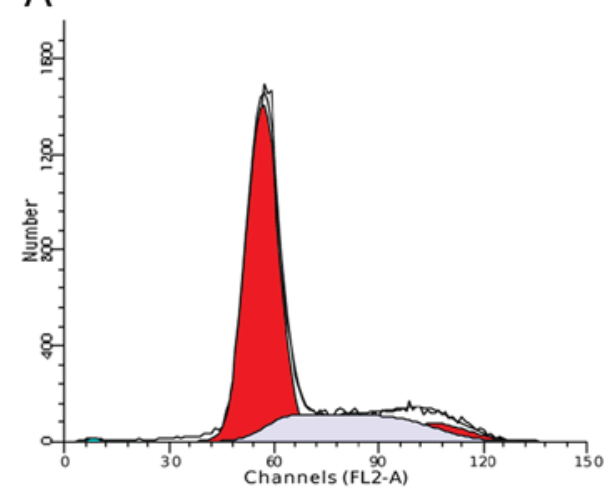

B

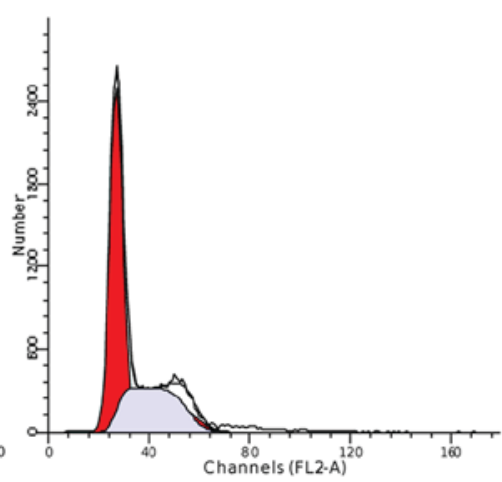

C

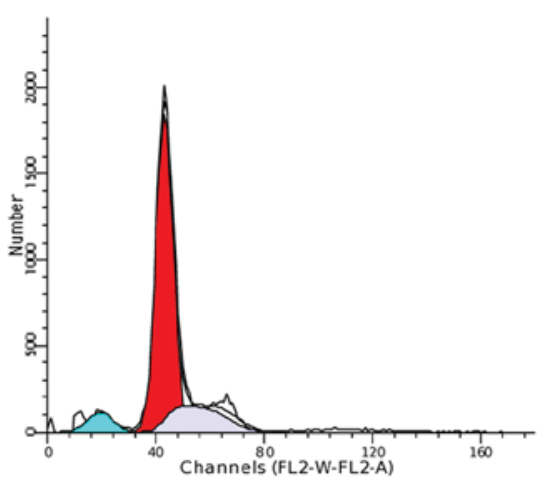

Figure 3. Cell cycle analysis. (A) The negative (medium-treated) group; (B) The blank (untreated) group; (C) The treatment (10 ${ }^{-4}$ mol/1 theophylline) group.

proliferation of SW480 cell through regulation of the cell cycle $\mathrm{G}_{0} / \mathrm{G}_{1}$ phase transition. Taken together, the results of the present study revealed that the pan-chitinase inhibitor theophylline suppressed rectal cancer SW480 cell proliferation by inhibiting YKL-40 expression, which may occur partly through arrest at the $\mathrm{G}_{0} / \mathrm{G}_{1}$ phase of the cell cycle.

Angiogenesis is necessary for the progression of colorectal cancer (30). Angiopoietin-2, a member of the angiopoietin family, binds to the endothelium-specific receptor TEK tyrosine kinase (Tie2) and serves a notable role in maintaining normal vasculature through the modulation of vessel stability (31). High expression of angiopoietin-2 has been associated with several cancer types, including lung, oral, nasopharyngeal and kidney cancer (32-35). The concentration of angiopoietin-2 was higher in patients with colon cancer and in colorectal mice models than in healthy patients or animals, and circulating angiopoietin-2 levels were reported to predict an unfavorable outcome in metastatic colorectal carcinoma $(36,37)$. Angiopoietin-2 caninduce anarchical blood vessel organization during cancer progression and enhance the effect of vascular endothelial growth factor during active neovascularization $(38,39)$. Additionally, angiopoietin-2 serves a notable role in the migration and invasion of a malignancy, and is partly responsible for inducing abnormal epithelial-mesenchymal transition (40). Upregulation of angiopoietin-2 expression was observed in diverse human malignant tumors, but notable expression does not occur in healthy individuals, meaning it may represent a novel mechanistically directed target for antitumor therapy. The blockade of angiopoietin/Tie2 signaling prevented the recruitment of myeloid cells in a colon cancer model, whereas blocking angiopoietin-2 resulted in limiting tumor metastasis $(41,42)$. In addition, a peptibody that blocks angiopoietin-2 used to treat ovarian cancer is currently being evaluated in a phase III clinical trial (43).

YKL-40 has been demonstrated to be a novel proangiogenic factor (44). YKL-40 induces the migration of vascular smooth muscle cells (VSMCs) and promotes the attachment and spreading of VSMCs (45). Ngernyuang et al (46) demonstrated that YKL-40 could accelerate tumor cell proliferation by promoting angiogenesis. Zhang et al (47) reported that microvessel density was correlated with YKL-40 expression intensity $(\mathrm{r}=0.376, \mathrm{P}=0.001)$ and the proportion of $\mathrm{YKL}-40$ expression ( $\mathrm{r}=0.364, \mathrm{P}=0.002)$, and $\mathrm{YKL}-40$ may serve a role in angiogenesis in clear cell renal cell carcinoma. Another study indicated that overexpression of YKL-40 could increase the levels of blood vasculature formed in rectal cancer SW480 cells, and also enhance the migration and tube formation of umbilical vein endothelial cells (48). In the present study, the expression level of angiopoietin-2 in SW480 cell was significantly decreased upon blockade of YKL-40. From these results, it can be deduced that YKL-40 expression is associated with angiopoietin-2 expression: Suppression of YKL-40 expression resulted in a decreased level of angiopoietin-2 in SW480 cells, which may be one reason for the pathogenesis of rectal cancer.

In summary, the findings of the present study support those of previous studies, which demonstrated that theophylline exerts an antitumor effect. The mechanism by which this occurs may involve the downregulation of YKL-40 expression; the cell cycle was arrested at the $G_{1}$ phase the expression of angiopoietin-2 protein was suppressed. Next, further research, such as an experimental animal study, may be required to understand better the functions of YKL-40 in rectal cancer development and progression.

\section{Acknowledgements}

Not applicable.

\section{Funding}

The present study was supported by grants from the Science and Technology Department of Sichuan Province (no. 2017JY0116), the Youth Fund from the Administration of Traditional Chinese Medicine of Sichuan Province in China (no. 2016Q089) and the Fund from Synergetic Development Research Center of Sichuan Traditional Chinese Medicine Culture (no. ZYYWH1613).

\section{Availability of data and materials}

All datasets generated and analyzed in the present study are included in this published article.

\section{Authors' contributions}

HP conceived and designed the study, and collected the data. HP, QS and ZCL conducted experiments. XHZ, MSP and ZBL analyzed the data. HP and QS wrote the manuscript. 


\section{Ethics and consent to participate}

The study was approved by Nanchong City Central Hospital Ethical Committee, and written informed consent was gained from all participants.

\section{Consent for publication}

Written informed consent was gained from all participants.

\section{Competing interests}

The authors declare that they have no competing interests.

\section{References}

1. Zhiqin W, Palaniappan S and Raja Ali RA: Inflammatory bowel disease-related colorectal cancer in the asia-pacific region: Past, present, and future. Intest Res 12: 194-204, 2014

2. Aklilu M and Eng C: The current landscape of locally advanced rectal cancer. Nat Rev Clin Oncol 8: 649-659, 2011.

3. Volck B, Price PA, Johansen JS, Sørensen O, Benfield TL, Nielsen HJ, Calafat J and Borregaard N: YKL-40, a mammalian member of the chitinase family, is a matrix protein of specific granules in human neutrophils. Proc Assoc Am Physicians 110: 351-360, 1998

4. Junker N, Johansen JS, Andersen CB and Kristjansen PE: Expression of YKL-40 by peritumoral macrophages in human small cell lung cancer. Lung Cancer 48: 223-231, 2005.

5. Johansen JS, Schultz NA and Jensen BV: Plasma YKL-40: A potential new cancer biomarker? Future Oncol 5: 1065-1082, 2009.

6. Johansen JS, Høyer PE, Larsen LA, Price PA and Møllgård K: YKL-40 protein expression in the early developing human musculoskeletal system. J Histochem Cytochem 55: 1213-1228, 2007.

7. Brøchner CB, Johansen JS, Larsen LA, Bak M, Mikkelsen HB, Byskov AG, Andersen CY and Møllgård K: YKL-40 is differentially expressed in human embryonic stem cells and in cell progeny of the three germ layers. J Histochem Cytochem 60 188-204, 2012

8. Francescone RA, Scully S, Faibish M, Taylor SL, Oh D, Moral L, Yan W, Bentley B and Shao R: Role of YKL-40 in the angiogenesis, radioresistance, and progression of glioblastoma. J Biol Chem 286: 15332-15343, 2011.

9. Lee CG, Hartl D, Lee GR, Koller B, Matsuura H, Da Silva CA, Sohn MH, Cohn L, Homer RJ, Kozhich AA, et al: Role of breast regression protein 39 (BRP-39)/Chitinase 3-like-1 in Th2 and IL-13-induced tissue responses and apoptosis. J Exp Med 206: 1149-1166, 2009.

10. Thongsom S, Chaocharoen W, Silsirivanit A, Wongkham S, Sripa B, Choe H, Suginta W and Talabnin C: YKL-40/ chitinase-3-like protein 1 is associated with poor prognosis and promotes cell growth and mgration of cholangiocarcinoma. Tumour Biol 37: 9451-9463, 2016.

11. Chiang YC, Lin HW, Chang CF, Chang MC, Fu CF, Chen TC, Hsieh SF, Chen CA and Cheng WF: Overexpression of CHI3L1 is associated with chemoresistance and poor outcome of epithelial ovarian carcinoma. Oncotarget 6: 39740-39755, 2015.

12. Zheng X, Xing S, Liu XM, Liu W, Liu D, Chi PD, Chen H, Dai SQ, Zhong Q, Zeng MS and Liu WL: Establishment of using serum YKL-40 and SCCA in combination for the diagnosis of patients with esophageal squamous cell carcinoma. BMC Cancer 14: 490, 2014.

13. Wang D, Zhai B, Hu F, Liu C, Zhao J and Xu J: High YKL-40 serum concentration is correlated with prognosis of Chinese patients with breast cancer. PLoS One 7: e51127, 2012.

14. Kırankaya Güneş A, Gül Ş, Tutar N, Özgül MA, Çetinkaya E, Zengi $\mathrm{O}$ and Onaran H: The place of YKL-40 in non-small cell lung cancer. Tuberk Toraks 62: 273-278, 2014.

15. Zhu CB, Wang C, Chen LL, Ma GL, Zhang SC, Su L, Tian JJ and Gai ZT: Serum YKL-40 independently predicts outcome after transcatheter arterial chemoembolization of hepatocellular carcinoma. PLoS One 7: e44648, 2012.
16. Vom Dorp F, Tschirdewahn S, Niedworok C, Reis H, Krause H, Kempkensteffen C, Busch J, Kramer G, Shariat SF, Nyirady P, et al: Circulating and tissue expression levels of YKL-40 in renal cell cancer. J Urol 195: 1120-1125, 2016.

17. Johansen JS, Christensen IJ, Jørgensen LN, Olsen J, Rahr HB, Nielsen KT, Laurberg S, Brünner N and Nielsen HJ: Serum YKL-40 in risk assessment for colorectal cancer: A prospective study of 4,496 subjects at risk of colorectal cancer. Cancer Epidemiol Biomarkers Prev 24: 621-626, 2015.

18. Chen CC, Llado V, Eurich K, Tran HT and Mizoguchi E: Carbohydrate-binding motif in chitinase 3-like 1 (CHI3L1/YKL-40) specifically activates Akt signaling pathway in colonic epithelial cells. Clin Immunol 140: 268-275, 2011.

19. Chen CC,Pekow J,Llado V, Kanneganti M,Lau CW,Mizoguchi A, Mino-Kenudson M, Bissonnette M and Mizoguchi E: Chitinase 3like-1 expression in colonoic epithelial cells as a potentially novel marker for colitis-associated neoplasia. Am J Pathol 179: 1494-1503, 2011.

20. Kraus S and Arber N: Inflammation and colorectal cancer. Curr Opin Pharmacol 9: 405-410, 2009.

21. Shao R, Hamel K, Petersen L, Cao QJ, Arenas RB, Bigelow C, Bentley B and Yan W: YKL-40, a secreted glycoprotein, promotes tumor angiogenesis. Oncogene 28: 4456-4468, 2009.

22. Recklies AD, White $C$ and Ling $H$ : The chitinase 3-like protein human cartilage glycoprotein 39 (HC-gp39) stimulates proliferation of human connective-tissue cells and activates both extracellular signal-regulated kinase- and protein kinase B-mediated signaling pathways. Biochem J 365: 119-126, 2002.

23. Lee CG, Da Silva CA, Dela Cruz CS, Ahangari F, Ma B, Kang MJ, He CH, Takyar S and Elias JA: Role of chitin and chitinase/chitin-like proteins in inflammation, tissue remodeling, and injury. Annu Rev Physiol 73: 479-501, 2011.

24. Low D, Subramaniam R, Lin L, Aomatsu T, Mizoguchi A, Ng A, DeGruttola AK, Lee CG, Elias JA, Andoh A, et al: Chitinase 3like 1 induces survival and proliferation of intestinal epithelial cells during chronic inflammation and colitis-associated cancer by regulating S100A9. Oncotarget 6: 36535-36550, 2015.

25. Okubo S, Uto T, Goto A, Tanaka H, Nishioku T, Yamada K and Shoyama Y: Berberine induces apoptotic cell death via activation of caspase-3 and -8 in HL-60 human leukemia cells: Nuclear localization and structure-activity relationships. Am J Chin Med 45: 1497-1511, 2017.

26. Lee IA,Kamba A,Low D and Mizoguchi E: Novel methylxanthine derivative-mediated anti-inflammatory effects in inflammatory bowel disease. World J Gastroenterol 20: 1127-1138, 2014.

27. Chang YL,Hsu YJ, Chen Y,Wang YW and Huang SM: Theophylline exhibits anti-cancer activity via suppressing SRSF3 in cervical and breast cancer cell lines. Oncotarget 8: 101461-101474, 2017.

28. Sheng H, Shao J, Townsend CM Jr and Evers BM: Phosphatidylinositol 3-kinase mediates proliferative signals in intestinal epithelial cells. Gut 52: 1472-1478, 2003.

29. Eurich K, Segawa M, Toei-Shimizu S and Mizoguchi E: Potential role of chitinase 3-like-1 in inflammation-associated carcinogenic changes of epithelial cells. World J Gastroenterol 15: 5249-5259, 2009

30. Mihalache A and Rogoveanu I: Angiogenesis factors involved in the pathogenesis of colorectal cancer. Curr Health Sci J 40, 5-11, 2014.

31. Hu B and Cheng SY: Angiopoietin-2: Development of inhibitors for cancer therapy. Curr Oncol Rep 11: 111-116, 2009.

32. Fawzy A, Gaafar R, Kasem F, Ali SS, Elshafei M and Eldeib M: Importance of serum levels of angiopoietin-2 and survivin biomarkers in non-small cell lung cancer. J Egypt Natl Cancer Inst 24: 41-45, 2012

33. Li C, Sun CJ, Fan JC, Geng N, Li CH, Liao J, Mi K, Zhu GQ, $\mathrm{Ma} \mathrm{H}$, Song YF, et al: Angiopoietin-2 expression is correlated with angiogenesis and overall survival in oral squamous cell carcinoma. Med Oncol 30: 571, 2013.

34. Chen HH, Weng BQ, Cheng KJ, Liu HY, Wang SQ and Lu YY: Effect of the vascular endothelial growth factor expression level on angiopoietin-2-mediated nasopharyngeal carcinoma growth. Vasc Cell 6: 4, 2014

35. Rautiola J, Lampinen A, Mirtti T, Ristimäki A, Joensuu H, Bono P and Saharinen P: Association of angiopoietin-2 and Ki-67 expression with vascular density and sunitinib response in metastatic renal cell carcinoma. PLoS One 11: e0153745, 2016.

36. Goede V, Coutelle O, Neuneier J, Reinacher-Schick A, Schnell R, Koslowsky TC, Weihrauch MR, Cremer B, Kashkar H, Odenthal M et al: Identification of serum angiopoietin-2 as a biomarker for clinical outcome of colorectal cancer patients treated with bevacizumab-containing therapy. Br J Cancer 103: 1407-1414, 2010. 
37. Liu WX, Gu SZ, Zhang S, Ren Y, Sang LX and Dai C: Angiopoietin and vascular endothelial growth factor expression in colorectal disease models. World J Gastroenterol 21 : 2645-2650, 2015.

38. Falcón BL, Hashizume H, Koumoutsakos P, Chou J, Bready JV, Coxon A, Oliner JD and McDonald DM: Contrasting actions of selective inhibitors of angiopoietin-1 and angiopoietin-2 on the normalization of tumor blood vessels. Am J Pathol 1755 $2159-2170,2009$

39. Lobov IB, Brooks PC and Lang RA: Angiopoietin-2 displays VEGF-dependent modulation of capillary structure and endothelial cell survival in vivo. Proc Natl Acad Sci USA 99: 11205-11210, 2002.

40. Li C, Li Q, Cai Y, He Y, Lan X, Wang W, Liu J, Wang S, Zhu G, Fan J, et al: Overexpression of angiopoietin 2 promotes the formation of oral squamous cell carcinoma by increasing epithelial-mesenchymal transition-induced angiogenesis. Cancer Gene Ther 23: 295-302, 2016.

41. Huang H, Lai JY, Do J, Liu D, Li L, Del Rosario J, Doppalapudi VR, Pirie-Shepherd S, Levin N, Bradshaw C, et al: Specifically targeting angiopoietin-2 inhibits angiogenesis, Tie2-expressing monocyte infiltration, and tumor growth. Clin Cancer Res 17: 1001-1011, 2011.

42. MazzieriR,PucciF,Moi D,Zonari E, Ranghetti A,Berti A,PolitiLS, Gentner B, Brown JL, Naldini L and De Palma M: Targeting the ANG2/TIE2 axis inhibits tumor growth and metastasis by impairing angiogenesis and disabling rebounds of proangiogenic myeloid cells. Cancer Cell 19: 512-526, 2011.
43. Monk BJ, Poveda A, Vergote I, Raspagliesi F, Fujiwara K, Bae DS, Oaknin A, Ray-Coquard I, Provencher DM, Karlan BY, et al: Anti-angiopoietin therapy with trebananib for recurrent ovarian cancer (TRINOVA-1): A randomised, multicentre, doubleblind, placebo-controlled phase 3 trial. Lancet Oncol 15: 799-808, 2014.

44. Riabov V, Gudima A, Wang N, Mickley A, Orekhov A and Kzhyshkowska J: Role of tumor associated macrophage in tumor angiogenesis and lymphangiogenesis. Front Physiol 5: 75, 2014.

45. Nishikawa KC and Millis AJ: gp38k (CHI3L1) is a novel adhesion and migration factor for vascular cells. Exp Cell Res 287: 79-87, 2003.

46. Ngernyuang N, Francescone RA, Jearanaikoon P, Daduang J, Supoken A, Yan W, Shao R and Limpaiboon T: Chitinase 3 like 1 is associated with tumor angiogenesis in cervical cancer. Int J Biochem Cell Biol 51: 45-52, 2014.

47. Zhang JP, Yuan HX, Kong WT, Liu Y, Lin ZM, Wangs WP and Guo JM: Increased expression of Chitinase 3-like 1 and microvessel density predicts metastasis and poor prognosis in clear cell renal cell carcinoma. Tumour Biol 35: 12131-12137, 2014.

48. Kawada M, Seno H, Kanda K, Nakanishi Y, Akitake R, Komekado H, Kawada K, Sakai Y, Mizoguchi E and Chiba T: Chitinase 3 -like 1 promotes macrophage recruitment and angiogenesis in colorectal cancer. Oncogene 31: 3111-3123, 2012. 